\title{
SOSIALISASI DAMPAK KERUSAKAN RUMAH PASCA GEMPA DI DESA TAWA
}

\author{
Endah Harisun ${ }^{1}$ \\ ${ }^{1}$ Program Studi Arsitektur Fakultas Teknik Universitas Khairun, Ternate \\ email endah.harisun@unkhair.ac.id
}

\begin{abstract}
ABSTRAK
Menurut data yang diperoleh dari Badan Nasional Penanggulangan Bencana (BNPB), terdapat empat puluh lima (45) Desa yang terkena dampak yang cukup parah. Hal ini juga berlaku pada desa Tawa yang merupakan salah satu desa yang terkena dampak guncangan gempa bumi tersebut. Akibat guncangan gempa tersebut hampir seluruh bangunan di Desa Tawa roboh. Tujuan dari kegiatan sosialisasi dampak kerusakan rumah pasca gempa di desa Tawa yang terkena dampak bencana gempa bumi adalah meningkatnya pemahaman masyarakat tentang konstruksi rumah sederhana yang tahan gempa. Metode pelaksanaan sosialisasi yang digunakan dalam kegiatan Pengabdian Kepada Masyarakat (PKM) ini adalah kegiatan sosialisasi dan pendampingan kepada masyarakat. Dengan adanya kegiatan sosialisasi tentang dampak kerusakan rumah pasca gempa di desa Tawa, diharapkan masyarakat lebih memahami tentang konstruksi bangunan tahan gempa rumah sederhana dan juga pemahan yang mendalam tentang rumah Fala Kancing yang sudah menjadi tradisi lama yang telah diikuti secara turun-temurun (local genius).
\end{abstract}

Kata Kunci : sosialisasi, pasca gempa, desa Tawa.

\begin{abstract}
According to data obtained from the National Disaster Management Agency (BNPB), there are forty five (45) villages that were badly affected. This also applies to the village of Tawa which is one of the villages affected by the earthquake shocks. As a result of the earthquake shocks almost all buildings in Tawa Village collapsed. The purpose of the socialization activities of the impact of post-earthquake damage to houses in the Tawa village affected by the earthquake was to increase community understanding of the construction of simple earthquakeresistant houses. The method of implementing the socialization used in Community Service Activities (PKM) is a socialization activity and assistance to the community. With the socialization of the impact of post-earthquake damage to houses in Tawa village, it is hoped that the community will understand more about the construction of earthquake-resistant buildings, simple houses and also deep understanding of Fala Kancing's house which has become a long-standing tradition that has been followed for generations (local genius).
\end{abstract}

Keywords : post-earthquake, socialization, Tawa village. 


\section{PENDAHULUAN}

Gempa bumi merupakan salah satu dari bencana alam yang sangat menakutkan bagi kehidupan manusia. Gempa dapat terjadi karena ada efek dari bencana yang lain bahkan gempa sendiri dapat menimbulkan bencana alam yang lain (Rinaldi \& Purwantiasning, 2015).

Pada tanggal 14 Juli 2019 terjadi gempa bumi yang melanda Kabupaten Halmahera Selatan dengan skala 7,2 pada skala Richter. Menurut data yang diperoleh dari Badan Nasional Penanggulangan Bencana (BNPB), terdapat empat puluh lima (45) Desa yang terkena dampak yang cukup parah.

Wilayah Laut Maluku sering mengalami gempa susulan dengan magnitudo $\mathrm{Mw}=5$ hingga sekarang (Sinaga, 2016). Menurut data dari Badan Nasional Penanggulangan Bencana (BNPB). Sebelumnya fenomena gerombolan gempa bumi juga terdeteksi oleh jaringan BMKG di Halmahera Barat, Maluku Utara Indonesia pada Oktober 2015 hingga Februari 2016 (Dian Nugraha et al., 2017).

Gempa bumi yang telah terjadi di Kabupaten Halmahera Selatan beberapa waktu lalu, telah menyebabkan kerusakan pada rumah tinggal maupun bangunan yang lain. Kerusakan tersebut meliputi rusak dengan skala ringan, sedang, maupun berat. Dengan banyaknya kerusakan-kerusakan tersebut salah satu penyebabnya adalah tidak diikutinya kaidah bangunan tahan gempa pada saat mendirikan bangunan. Standar untuk bangunan tahan gempa sebenarnya telah diatur melalui peraturan pemerintah dalam hal ini adalah melalui Kementerian PUPR. Namun berdasarkan pengamatan di lapangan, masih banyak bangunan kurang memenuhi standar yang telah ditetapkan. Misalnya bangunan harus memiliki sloof, dinding dari bata yang seharusnya dilengkapi dengan kolom-kolom pengikat, agar bisa menjaga dinding tidak roboh meskipun terkena guncangan. Berdasarkan pengamatan di lapangan, hampir keseluruhan bangunan di desa Tawa yang roboh salah satu penyebabnya adalah kesalahan konstruksi.

Melalui kegiatan Fakultas Teknik peduli bencana gempa bumi Halmahera Selatan, pada tanggal 19 Juli 2019 tim Fakulas Teknik berangkat ke pusat daerah gempa dan bergabung dengan tim penyaluran, investigasi, dan tim relawan nasional. Kegiatan yang dilakukan adalah memberikan bantuan sosial serta investigasi awal penyebab kerusakan fisik pada fasilitas umum dan rumah penduduk. Desa Balitata merupakan desa yang dikunjungi untuk diinvestigasi masalah kerusakan bangunan. Melalui data dari desa tersebut, menjadi patokan dari Fakultas Teknik untuk melakukan sosialisasi dampak kerusakan rumah pasca gempa di desa-desa yang lain. Dengan tipologi bangunan yang hampir sama pada setiap desa di kawasan pantai pulau Halmahera Kabupaten Halmahera Selatan, dampak kerusakan pada bangunannya juga akan sama. Hal ini juga berlaku pada desa Tawa yang merupakan salah satu desa yang terkena dampak guncangan gempa bumi yang cukup parah. 


\section{METODE}

Berdasarkan latar belakang, tujuan dari kegiatan melakukan sosialisasi dampak kerusakan rumah pasca gempa di desa-desa yang lain yang terkena dampak bencana gempa bumi adalah meningkatnya pemahaman masyarakat tentang konstruksi rumah sederhana yang tahan gempa. Hasil dari investigasi dampak kerusakan rumah di desa Balitata menjadi rujukan untuk melakukan sosialisasi dampak kerusakan rumah pasca gempa di desa Tawa.

Menurut Arifin, kegiatan pasca gempa adalah : (i) Pendataan, (ii) Sosialisasi, (iii) Relokasi Pengungsi, (iv) Rehabilitasi, (v) Rekonstruksi dan (vi) Pengawasan (Arifin, 2005). Terpilihnya desa Tawa yang menjadi lokasi kegaiatan sosialisasi dampak kerusakan rumah pasca gempa, dikarenakan desa Tawa adalah salah satu desa yang paling parah terkena dampak dari gempa bumi. Hampir seluruh rumah maupun bangunan di desa Tawa ambruk akibat gempa bumi.

Di negara-negara yang telah maju, kegiatan memprediksi probabilitas dari kerusakan bangunan yang disebabkan oleh bencana gempa bumi sering dilakukan. Salah satu upaya yang di lakukan adalah mengevaluasi kerusakan pada bangunan berdasarkan peristiwa gempa bumi yang telah terjadi sebelumnya. Apabila pada masa yang akan datang terjadi gempa, kerusakan dari bangunan akan dapat dikurangi dengan upaya meningkatkan kapasitas dari bangunan yang didasarkan dari hasil sebelumnya (Bawono, 2016).

Metode pelaksanaan yang digunakan dalam kegiatan Pengabdian Kepada Masyarakat (PKM) ini adalah tiga tahap yaitu tahap persiapan, pelaksanaan dan tahap evaluasi (Rijati, Intan, \& Subekti, 2017).

1. Tahap Persiapan

Pada tahap ini dilakukan survey pada bangunan-bangunan dampak gempa bumi di desa Tawa untuk mendapatkan gambaran umum dan objek terhadap permasalahan yang dihadapi mitra kegiatan Pengabdian Kepada Masyarakat (PKM) ini. Berdasarkan permasalahan tersebut kemudian disusun rencana kegiatan sosialisasi berdasarkan tema yang menjadi permasalahan utama. Rencana tersebut meliputi jenis dan jadwal kegiatan, pemilihan dan penentuan media dan materi setiap kegiatan, dan penanggung jawab dan pelaksana setiap kegiatan.

\section{Tahap Pelaksanaan}

Tahap pelaksanaan melalui beberapa tahap yaitu : 
a. Melakukan kooridinasi dengan perangkat desa mengenai perizinan, waktu pelaksanaan kegiatan, tempat kegiatan dan peserta kegiatan.

b. Melakukan pendampingan kepada masyarakat yang sedang melakukan pembangunan baik rumah tinggal maupun fasilitas umum.

3. Tahap Evaluasi

Pada tahapan ini, akan dilakukan evaluasi berdasarkan hasil dari kegiatan pembangunan rumah tinggal maupun fasilitas umum pasca gempa :

a. Memberikan modul dan pedoman pembangunan bangunan tahan gempa.

b. Terus berkoordinasi dengan perangkat desa setempat tentang jumlah rumah yang telah dibangun, kendala yang diahadapi pada saat membangun.

c. Kebutuhan material bangunan yang diperlukan.

Hasil evaluasi akan disusun sebagai laporan kegiatan Pengabdian Kepada Masyarakat (PKM) dan akan dijadikan laporan awal untuk kelanjutan kegiatan PKM selanjutnya

\section{PEMBAHASAN}

\section{a. Tahap Pelaksanaan}

Persiapan pelaksanaan sosialisasi adalah dengan berkoordinasi dengan kepala desa Tawa tentang tempat pelaksanaan sosialisasi dan kemudian persiapan acara seperti : persiapan soundsystem, infocus, konsumsi dan pemasangan poster kegiatan.
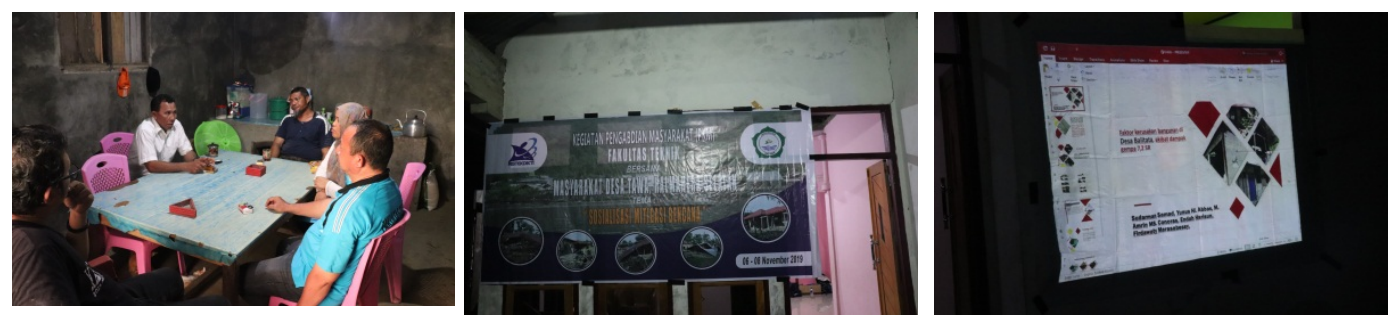

Gambar 1. Kegiatan persiapan sosialisasi dampak kerusakan rumah pasca gempa di desa Tawa

Pelaksanaan sosialsisasi dilakukan di rumah kepala desa Tawa. Hal ini dilakukan karena balai pertemuan desa mengalami kerusakan akibat gempa. Kegiatan sosialisasi di malam hari dikarenakan pada siang hari masyarakat desa Tawa sibuk bekerja membangun rumah-rumah yang runtuh serta sebagian bekerja di lahan perkebunan.

Waktu pelaksanaan sosialisasi adalah pada tanggal 6 November 2019, sedangkan metode sosialisasi adalah pemberian materi dan dilanjutkan dengan tanya jawab. 

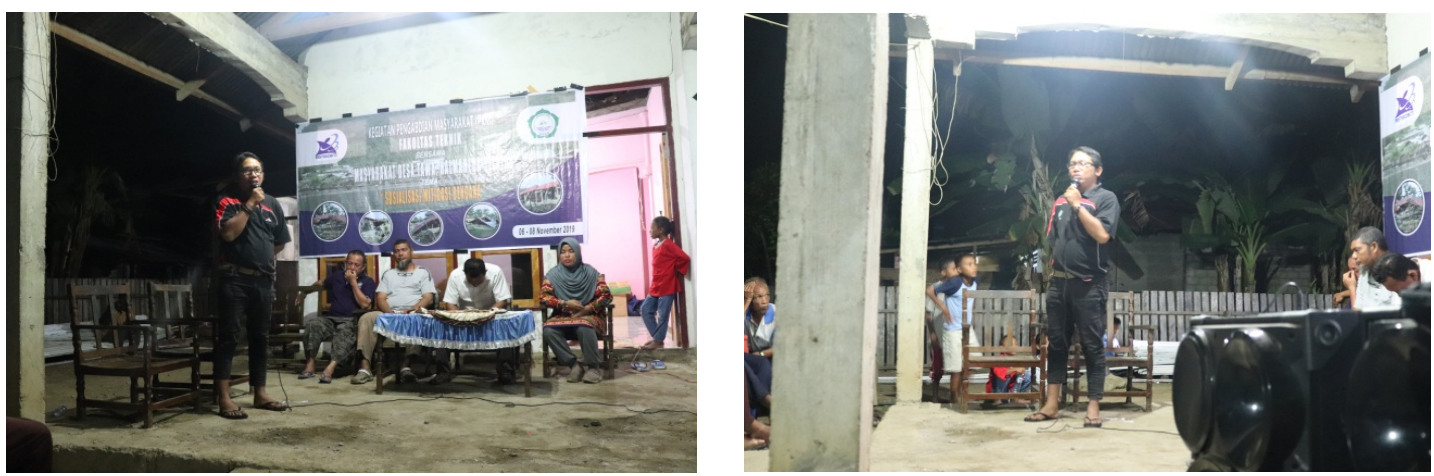

Gambar 2. Kegiatan sosialisasi dampak kerusakan rumah pasca gempa di desa Tawa

Materi sosialisasi ini terfokus pada kerentanan (vulnerability) pada fisik bangunan. Secara fisik, kerentanan bagi masyarakat adalah ketidakmampuan menghadapi bahaya atau ancaman misalnya kekuatan bangunan rumah pada masarakat yang berada di daerah rawan gempa (BNPB, 2008).

Prinsip bangunan tahan gempa (Zulfiar, Jayady, \& Jati Saputra, 2018) :

1. Kejadian gempa ringan, bangunan tidak seharusnya mengalami kerusakan pada komponen non struktural ataupun komponen struktural.

2. Kejadian gempa sedang, bangunan boleh mengalami kejadian kerusakan pada komponen non struktural seperti dinding retak, dan plafond runtuh. Bangunan tidak boleh kerusakan pada komponen struktural seperti sloof, kolom dan balok.

3. Kejadian gempa besar, bangunan boleh mengalami kerusakan pada kedua komponen baik struktural maupun non struktural namun jiwa dari penghuni rumah akan selamat dikarenakan sebelum bangunan runtuh, masih terdapat cukup waktu bagi penghuni rumah untuk lari keluar.
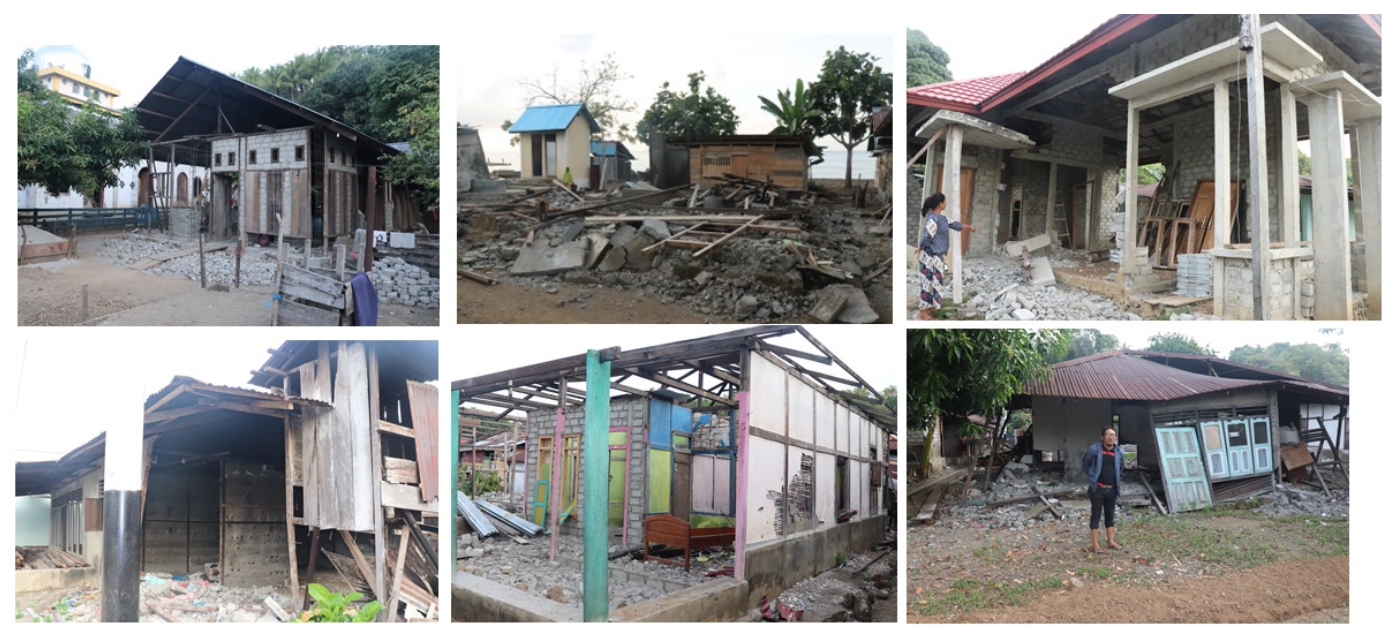

Gambar 3. Kerusakan rumah pasca gempa di desa Tawa 
Kondsi rumah yang terdapat pada desa Tawa hampir seluruhnya rusak total. Berdasarkan pengamatan di lapangan, struktur rumah di desa Tawa hampir sama dengan sruktur rumah di desa Balitata dan desa sekitarnya sehingga kerentanan bangunan yang dialami hampir sama pada setiap desa di dataran pulau Halmahera kabupaten Halmahera Selatan. Faktor lain yang berpengaruh adalah pemahaman para tukang bangunan tentang cara membangun rumah tinggal dengan menggunakan konstruksi rumah tradisional Maluku Utara masih kurang. Banyak bangunan di desa Tawa menggunakan konstruksi rumah Fala Kancing.

Kerentanan suatau bencana adalah penyebab rusaknya bangunan dan juga pengaruh kemunduran pengetahuan lokal dan kapasitas serta kondisi kemiskinan (Jigyasu \& Consultant, n.d.).

Berikut adalah beberapa penyebab rumah di desa Tawa yang ambruk :

1. Sebagian rumah tidak memiliki pondasi yang cukup dalam. Penggunaan material batu karang laut juga berpengaruh pada kekuatan pondasi rumah tersebut.

2. Tulangan rangka yang digunakan pada rumah menggunakan balok kayu sedangkan bahan pengisi bangunan adalah batu bata press yang terbuat dari semen sehingga balok kayu tidak mampu menahan beban dindng tersebut.

3. Balok kayu yang digunakan sebagai tulangan rangka, dipasang tanpa ada ikatan dengan sloof pada pondasi dan bahkan sebagian rumah tidak menggunakan sloof sebagai konstruksi pengikat kolom.

4. Penggunaan angkur pengikat atara kolom dan dinding bata hanya mengandalkan paku yang ditancapkan pada kolom kayu dan ukurannya sangat pendek bahkan pada beberapa rumah tidak menggunakan angkur penahan dinding.

5. Kuda-kuda atap tidak diikat dengan angkur pada ring balok bangunan pada kebanyakan rumah di desa Tawa.

6. Bangunan-bangunan dengan konstruksi rumah beton kurang memperhatikan ketentuan-ketentuan dalam pembangunan gedung.

Penyelenggaraan pembangunan bangunan (gedung dan bukan gedung) secara garis besar terdiri dari tiga tahapan antara lain : pertama tahap perencanaan dan perancangan, kedua tahap pelaksanaan, dan ketiga pengawasan dan monitoring (pengendalian). Untuk itu penyelenggaraan bangunan perlu diatur ketentuan pengendalian dan ketentuan dalam tiga tahapan tersebut di atas (Harisun, 2010).

Setelah memberikan materi sosialisai tentang dampak kerusakan rumah pasca gempa di desa Tawa, dilanjutkan dengan sesi tanya jawab dari masyarakat. 


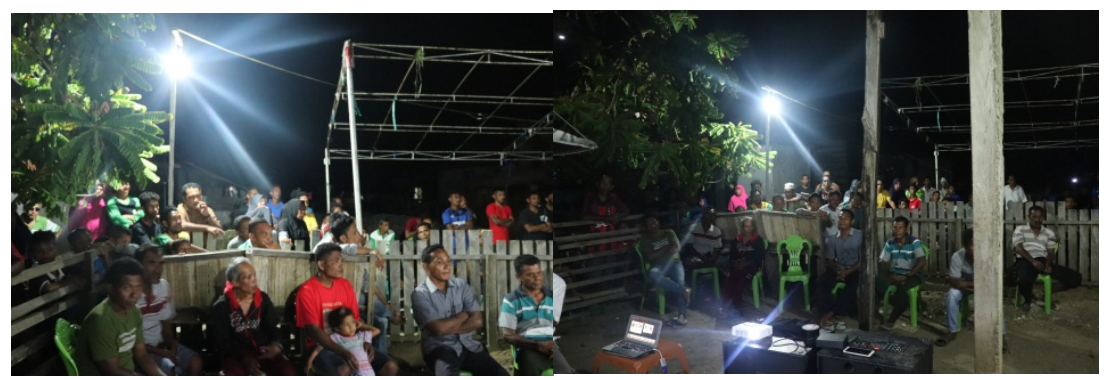

Gambar 4. Suasana sosialisasi tentang dampak kerusakan rumah pasca gempa di desa Tawa

\section{b. Kegiatan Pendampingan}

Pada kegiatan ini, dilakukan pendampingan dengan terlibat langsung ke masyarakat yang sedang membangun rumah tinggalnya ataupun fasilitas umum pasca gempa di Desa Tawa.
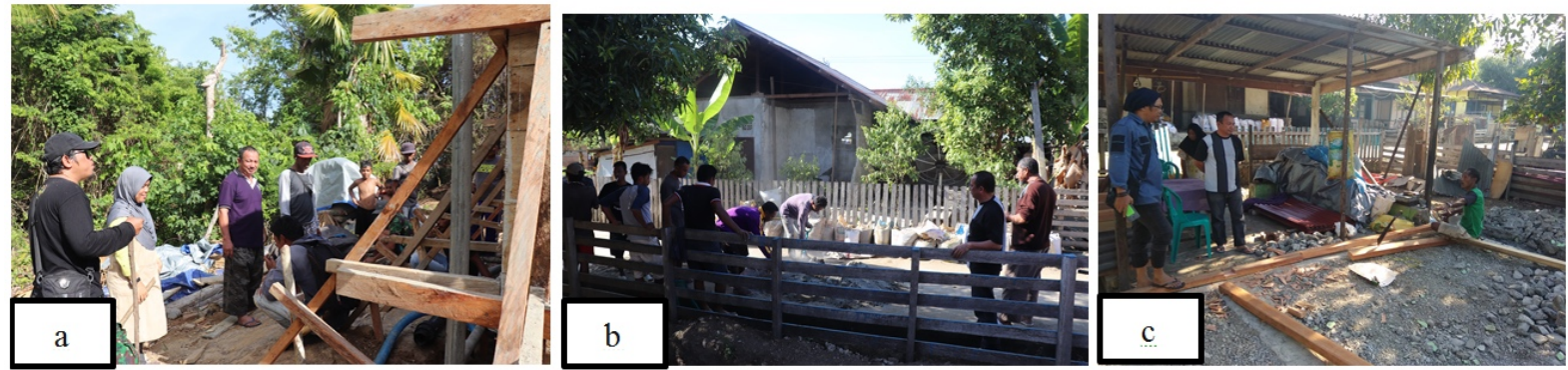

Gambar 5. Suasana kegiatan pendampingan kegiatan masyarakat

Pada kegitan pendampingan yang merupakan tindak lanjut dari kegiatan sosialisasi, terdiri dari kegiatan pendampingan pembangunan bak air seperti terlihat pada gambar 5a. pada kegiatan ini masyarakat diberikan arahan terhadap prinsip-prinsip membangun bak air yang sesuai dengan bangunan tahan gempa dengan menggunakan struktur beton. Kemudian dilanjutkan dengan pendampingan kegiatan memperbaiki jalan setapak dan tempat wudhu masjid (gambar 5b).

Karena dampak yang paling besar adalah kerusakan pada rumah tinggal, kegiatan pendampingan ini juga melakukan konsultasi langsung di lapangan terhadap masyarakat yang sedang membangun rumah kembali seperti terlihat pada gambar 5c. Diharapkan dengan mendampingi langsung di lapangan, masyarakat langsung dapat mempraktekan teori yang didapat pada kegiatan sosialisasi.

\section{c. Tahap Evaluasi}

Pada tahap terakhir tim PKM dari Fakultas Teknik bersama perangkat desa melakukan evaluasi tentang proses jalannya sosialisasi dan akan dijadikan bahan pertimbangan pada kegiatan-kegiatan berikutnya di desa Tawa. 


\section{SIMPULAN}

Dengan adanya kegiatan sosialisasi tentang dampak kerusakan rumah pasca gempa di desa Tawa dan kegiatan pendampingan langsung ke masyarakat, diharapkan masyarakat lebih memahami tentang konstruksi bangunan tahan gempa rumah sederhana dan juga pemahaman yang mendalam tentang rumah Fala Kancing yang sudah menjadi tradisi lama yang telah diikuti secara turun-temurun (local genius).

Kegiatan Fakultas Teknik Peduli Gempa Halmahera Selatan yang difokuskan pada desa Tawa diharapkan dapat membantu meringankan beban dari masyarakat setempat baik berupa materil (bahan pokok, bahan bangunan dan lain-lain), imateril (kegiatan sosialisasi) dan pendampingan langsung pada pembangunan fasilitas desa maupun rumah tinggal.

Kedepannya, dengan adanya kejadian gempa tersebut dapat jadi pelajaran untuk menghadapi bencana serupa. Kerusakan yang disebabkan oleh gempa tersebut harus dijadikan acuan dalam rekonstruksi di Maluku Utara, mengingat tingkat kegempaan di Propinsi Maluku Utara cukup tinggi, perlu ada program retrofitting untuk bangunan-bangunan yang bertahan tapi terindikasi rawan terhadap gempa. Perlu lebih ditingkatkan lagi sosialisasi standar bangunan tahan gempa untuk wilayah Maluku Utara dan sekitarnya.

\section{DAFTAR PUSTAKA}

Arifin, S. (2005). Strategi Untuk Mengurangi Kerusakan Lingkungan yang Diakibatkan oleh Gempa dan Gelombang Tsunami. 02 (01), 28-33.

Bawono, A. S. (2016). Studi Kerentanan Bangunan Akibat Gempa: Studi Kasus. JURNAL ILMIAH SEMESTA TEKNIKA, 19(1), 90-97.

BNPB. (2008). Peraturan Kepala Badan Nasional Penanggulangan Bencana Nomor 10 Tahun 2008 Tentang Pedoman Komando Tanggap Darurat Bencana. Bnpb, 13. https://doi.org/10.1017/CBO9781107415324.004

Dian Nugraha, A., Ash Shiddiqi, H., Widiyantoro, S., Puspito, N. T., Triyoso, W., Wiyono, S., ... Rosalia, S. (2017). Hypocenter Relocation of Earthquake Swarm in West Halmahera, North Molucca Region, Indonesia by using Double-Difference Method and 3D Seismic Velocity Structure. IOP Conference Series: Earth and Environmental Science, 62(1), 3-7. https://doi.org/10.1088/1755-1315/62/1/012053

Harisun, E. (2010). KONSEP PENATAAN BANGUNAN GEDUNG DI KOTA TOBELO KABUPATEN HALMAHERA UTARA. Conference: Seminar Nasional Teknologi Ramah Lingkungan Dalam Pembangunan BerkelanjutanAt: Institut Teknologi Nasional Malang, (ISBN : 978-979-3984-30-8), 978979. 
Jigyasu, B. R., \& Consultant, C. (n.d.). SUSTAINABLE POST DISASTER RECONSTRUCTION THROUGH INTEGRATED RISK MANAGEMENT - THE CASE OF RURAL.

Rijati, S., Intan, T., \& Subekti, M. (2017). Sosialisasi Daur Ulang Sampah Sebagai Upaya Pengembangan EkoBudaya di Lingkungan Desa Sayang Jatinangor Kabupaten Sumedang. 1(2), 29-34.

Rinaldi, Z., \& Purwantiasning, A. W. (2015). ANALISA KONSTRUKSI TAHAN GEMPA RUMAH TRADISIONAL SUKU BESEMAH DI KOTA PAGARALAM SUMATERA SELATAN. Seminar Nasional Sains Dan Teknologi 2015, (November), 1-10.

Sinaga, G. H. D. (2016). Coulomb stress analysis of West Halmahera earthquake mw $=7$. 2 to mount Soputan and Gamalama volcanic activities Coulomb stress analysis of West Halmahera earthquake mw $=7.2$ to mount Soputan and Gamalama volcanic activities. IOP Conf. Series: Earth and Environmental Science. https://doi.org/10.1088/1755-1315/56/1/01200

Zulfiar, M. H., Jayady, A., \& Jati Saputra, N. R. (2018). Kerentanan Bangunan Rumah Cagar Budaya Terhadap Gempa Di Yogyakarta. Jurnal Karkasa, 4(1), 5. https://doi.org/10.32531/jkar.v4i1.67 